\title{
Respiratory symptoms and ventilatory function changes in relation to length of exposure to cotton dust
}

\author{
E. ŽU S K IN and F. VALIĆ \\ Andrija Stampar School of Public Health, Zagreb University, Zagreb, Yugoslavia
}

\begin{abstract}
The prevalence of byssinosis, respiratory symptoms, acute changes of ventilatory capacity over the shift, and chronic changes of ventilatory capacity were studied in two groups of nonsmoking female workers exposed to practically identical concentrations of the same type of cotton dust but for very different periods of time (16 and 4 years respectively). The prevalence of non-specific respiratory symptoms increased with the duration of exposure to cotton dust only in the subjects with byssinosis. Exposure to cotton dust caused significant reductions over the shift of the mean $F V_{1.0}, F V C$ and PEF in all the groups of cotton workers examined. In byssinotics the reduction in ventilatory capacity was considerably greater in subjects with longer than in those with shorter exposure to cotton dust, while in non-byssinotics the response was approximately equal in the two groups. Inhalation of a bronchodilator at the end of the shift restored ventilatory function to its pre-shift values except in byssinotics with a longer duration of exposure to cotton dust. Chronic changes of ventilatory capacity developed only in subjects with a longer exposure to cotton dust and were common in the byssinotics.
\end{abstract}

Numerous epidemiological studies have shown that exposure to cotton dust may cause respiratory symptoms accompanied by changes of lung function. The diagnosis of byssinosis is based on the characteristic history of chest tightness, cough, and wheezing, predominantly on the first working day after a break of more than one day of exposure to active dust. Later, the same symptoms occur on subsequent days of the week, and chronic cough and dyspnoea may persist even during absence from work. Evidence of irreversible ventilatory insufficiency may then be found (Schilling et al., 1964).

The first report on respiratory function changes during the shift in cotton workers was by McKerrow, McDermott, Gilson, and Schilling (1958). Their findings have been confirmed by others in different countries (Schilling, Bouhuys, and Gilson, 1971).

Reports conflict on the relationships between the duration of exposure to vegetable dust and the prevalence of byssinosis and acute respiratory response. While Molyneux and Tombleson (1970) found a steady increase of byssinosis with duration of exposure up to 29 years in their study of 1,359 cotton workers, Batawi, Schilling, Valić, and
Walford (1964) and Bouhuys et al. (1969) had not observed this relationship. Batawi et al. (1964), however, found a high significant correlation between the fall of indirect maximum breathing capacity during the shift and the incidence of byssinosis.

The present study was undertaken to assess the influence of the duration of exposure to cotton dust on the development of symptoms of byssinosis and other non-specific respiratory symptoms, and on the severity of the acute and chronic ventilatory function responses.

\section{POPULATION AND METHODS}

SUBJECTS Two groups of non-smoking female cotton workers were selected. They were exposed to very similar airborne concentrations of the same type of cotton dust but differed very significantly in respect of duration of exposure. They work in two cotton mills processing fine-grade cotton. Both mills are situated in the same rural area away from other industries so that the general level of outdoor air pollution is low and similar. Sixty-nine workers were studied in mill $\mathrm{A}$ and 60 in mill $\mathrm{B}$. The subjects in mill A were considerably older and had a longer 
history of exposure to cotton dust (mean age 37 years, mean duration of exposure 16 years) than subjects in mill $B$ (mean age 27 years, mean duration of exposure 4 years).

ENVIRONMENTAL DUST MEASUREMENT Airborne dust samples were collected by means of two-stage dust samplers with a horizontal elutriator as the first stage (Hexhlet Sampler, Casella, London) (Wright, 1954). Mass concentrations of total and respirable dust were measured.

RESPIRATORY SYMPTOMS Respiratory symptoms and occupational histories were recorded using the standard Medical Research Council questionnaire on respiratory symptoms, extended by adding questions on byssinosis (Schilling et al., 1964).

Definitions. The following definitions were used. Persistent cough or phlegm: cough or sputum production on most days for at least three months per year

Chronic bronchitis: cough and sputum on most days for a minimum of three months in the year and for not less than two successive years

Dyspnoea grade 3: short of breath when walking at own pace on the level; grade 4: forced to stop for breath when walking at own slow pace on the level

The severity of the symptoms of byssinosis was graded clinically according to Schilling et al. (1964):

grade 1/2: occasional chest tightness on Mondays

grade 1: chest tightness or difficulty in breathing on every Monday at work

grade 2: chest tightness or difficulty in breathing during work on Mondays and other working days.

Functional grading of the effect of cotton dust was made as suggested by Bouhuys, Gilson, and Schilling (1970)-(Table 5).

VENTILATORY FUNCTION The one-second forced expiratory volume $\left(F E V_{1.0}\right)$ and forced vital capacity (FVC) were measured in all subjects with Bernstein type spirometers. After a rest of 5 minutes, peak expiratory flow (PEF) was recorded on a Wright peak flowmeter (Wright and McKerrow, 1959). The mean of the two highest of five readings was taken as the result. $\mathrm{FEV}_{1.0}$ and FVC values were corrected to BTPS. Measurements were performed on the first working day of the week before and after the shift. $\mathrm{FEV}_{1.0}$ values before the first working day were compared with the expected FEV 1.0 obtained from the Veterans Administration-Army Cooperative Study nomogram for normal females. In two groups of volunteers (30 in mill $A$ and 46 in mill $B$ ) a bronchodilator (Alupent ${ }^{1}$ ) was administered at the end of the shift by a pocket nebulizer (two doses of $750 \mu \mathrm{g}$ each). The ventilatory function measurements were repeated about 15 minutes after the inhalation of the bronchodilator.

1 Orciprenaline: 1-(3,5-dihydroxyphenyl)-2-isopropylaminoethanol sulphate

${ }^{2}$ Alupent and nebulizers were supplied by Messrs. C. H. Boehringer Sohn, Ingelheim, Germany
RESULTS

DUST CONCENTRATIONS Mean concentrations of total and respirable airborne cotton dust in the two mills are presented in Table $I$. The exposure levels were very similar in both mills.

T A B L E I

MEAN DUST CONCENTRATIONS

\begin{tabular}{c|c|cc}
\hline Mill & $\begin{array}{c}\text { No. of } \\
\text { Samples }\end{array}$ & $\begin{array}{c}\text { Total Dust } \\
\left(\mathrm{mg} / \mathrm{m}^{3}\right)\end{array}$ & $\begin{array}{c}\text { Respirable Dust } \\
\left(\mathrm{mg} / \mathrm{m}^{2}\right)\end{array}$ \\
\hline A & 21 & 4.049 & 1.063 \\
B & 27 & 4.177 & 1.444 \\
\hline
\end{tabular}

RESPIRATORY SYMPTOMS Twelve $(17 \cdot 4 \%)$ of 69 examined workers in mill A had clinical symptoms of byssinosis. A higher prevalence of byssinosis was found in mill B $(28.5 \%)$ but the difference was not statistically significant $(P>0.05)$.

Table II shows the prevalence of respiratory symptoms separately in subjects with and without byssinosis. These results indicate an association between the prevalence of persistent cough, sputum production, chronic bronchitis, and duration of exposure to cotton dust in workers with byssinosis. In subjects without byssinosis there was practically no difference in the prevalence of respiratory symptoms between workers with longer or shorter exposures to cotton dust. In mill A, a significantly higher prevalence of persistent cough and sputum and chronic bronchitis was found in byssinotics than in non-byssinotics $(P<0.01)$. These differences were not evident in mill $B(P>0.05)$.

ACUTE EFFECTS OF COITON DUST EXPOSURE ON VENTILATORY FUNCTION Significant reductions in FEV $_{1 \cdot 0}$, FVC, and PEF $(P<0.01)$ over the work shift were recorded in all cotton workers examined (Table III). The mean reductions of ventilatory capacity in byssinotics in mill A were greater than in byssinotics in mill $\mathrm{E}$, but the difference was statistically significant only in regard to PEF $(P<0.05)$. In workers without byssinosis the reductions over the work shift were similar in both mills. The byssinotics in mill $\mathbf{A}$ had significantly larger reductions of $\mathrm{FEV}_{1.0}$ and PEF than workers without byssinosis $(P<0.05)$. In mill $B$ the differences between byssinotics and non-byssinotics were not significant $(P>0.05)$.

In order to assess the effect of age and duration of exposure to cotton dust on acute lung function changes during the shift in the exposed group 
T A B LE II

PREVALENCE OF CHRONIC RESPIRATORY SYMPTOMS IN TWO COTTON MILLS

\begin{tabular}{|c|c|c|c|c|c|c|c|c|c|}
\hline Group & Mill & No. & $\begin{array}{c}\text { Average } \\
\text { Age } \\
\text { (yr) }\end{array}$ & $\begin{array}{c}\text { Average } \\
\text { Exposure } \\
\text { (yr) }\end{array}$ & $\begin{array}{c}\text { Persistent } \\
\text { Cough } \\
(\%)\end{array}$ & $\begin{array}{c}\text { Persistent } \\
\text { Sputum } \\
(\%)\end{array}$ & $\begin{array}{c}\text { Chronic } \\
\text { Bronchitis } \\
(\%)\end{array}$ & $\begin{array}{c}\text { Dyspnoea } \\
\text { Grade } \\
3 \text { and } 4 \\
(\%)\end{array}$ & $\begin{array}{c}\text { Nasal } \\
\text { Catarrh } \\
(\%)\end{array}$ \\
\hline With byssinosis & $\begin{array}{l}\mathbf{A} \\
\mathbf{B}\end{array}$ & $\begin{array}{l}12 \\
17\end{array}$ & $\begin{array}{l}36 \\
27\end{array}$ & $\begin{array}{r}15 \\
5\end{array}$ & $\begin{array}{l}83 \cdot 3 \\
41 \cdot 2\end{array}$ & $\begin{array}{l}41 \cdot 7 \\
29 \cdot 4\end{array}$ & $\begin{array}{l}41 \cdot 7 \\
17 \cdot 6\end{array}$ & $\begin{array}{l}16.7 \\
11.8\end{array}$ & $\begin{array}{l}58 \cdot 3 \\
64 \cdot 7\end{array}$ \\
\hline Without byssinosis & $\begin{array}{l}\mathbf{A} \\
\mathbf{B}\end{array}$ & $\begin{array}{l}57 \\
43\end{array}$ & $\begin{array}{l}37 \\
27\end{array}$ & $\begin{array}{r}17 \\
4\end{array}$ & $\begin{array}{l}28 \cdot 1 \\
25 \cdot 6\end{array}$ & $\begin{array}{l}10.5 \\
20.9\end{array}$ & $\begin{array}{l}10 \cdot 5 \\
16 \cdot 3\end{array}$ & $\begin{array}{r}5 \cdot 3 \\
11 \cdot 6\end{array}$ & $\begin{array}{l}43.9 \\
39.5\end{array}$ \\
\hline
\end{tabular}

T A B L E I I I

VENTILATORY FUNCTION CHANGES DURING THE SHIFT IN TWO COTTON MILLS

\begin{tabular}{|c|c|c|c|c|c|c|c|c|c|c|}
\hline \multirow{2}{*}{ Group } & \multirow{2}{*}{ Mill } & \multirow{2}{*}{$\begin{array}{l}\text { No. of } \\
\text { Workers }\end{array}$} & \multicolumn{6}{|c|}{ Mean Reductions } & \multicolumn{2}{|c|}{ FEV $_{1 \cdot 0} /$ FVC $\%$} \\
\hline & & & $\underset{(\mathrm{ml})}{\mathrm{FEV}_{\mathrm{r} \cdot 0}}$ & $\mathbf{P}$ & $\begin{array}{c}\text { FVC } \\
\text { (ml) }\end{array}$ & $\mathbf{P}$ & $\underset{(1 / \mathrm{min})}{\text { PEF }}$ & $\mathbf{P}$ & $\begin{array}{c}\text { Before } \\
\text { Shift }\end{array}$ & $\begin{array}{l}\text { After } \\
\text { Shift }\end{array}$ \\
\hline With byssinosis & $\begin{array}{l}\mathbf{A} \\
\mathbf{B}\end{array}$ & $\begin{array}{l}12 \\
17\end{array}$ & $\begin{array}{l}346 \\
174\end{array}$ & $\begin{array}{l}<0.01 \\
<0.01\end{array}$ & $\begin{array}{l}147 \\
134\end{array}$ & $\begin{array}{l}<0.01 \\
<0.01\end{array}$ & $\begin{array}{l}48 \\
27\end{array}$ & $\begin{array}{l}<0.01 \\
<0.01\end{array}$ & $\begin{array}{l}80 \cdot 0 \\
82 \cdot 1\end{array}$ & $\begin{array}{l}72 \cdot 8 \\
80 \cdot 4\end{array}$ \\
\hline Without byssinosis & $\begin{array}{l}\mathbf{A} \\
\mathbf{B}\end{array}$ & $\begin{array}{l}57 \\
43\end{array}$ & $\begin{array}{l}161 \\
123\end{array}$ & $\begin{array}{l}<0.01 \\
<0.01\end{array}$ & $\begin{array}{l}89 \\
98\end{array}$ & $\begin{array}{l}<0.01 \\
<0.01\end{array}$ & $\begin{array}{l}29 \\
22\end{array}$ & $\begin{array}{l}<0.01 \\
<0.01\end{array}$ & $\begin{array}{l}79 \cdot 7 \\
84 \cdot 2\end{array}$ & $\begin{array}{l}76 \cdot 9 \\
83 \cdot 2\end{array}$ \\
\hline
\end{tabular}

(byssinotics and non-byssinotics), partial correlation coefficients were calculated between age and length of exposure and acute $\mathrm{FEV}_{1 \cdot 0}$ reductions. Eliminating the effect of age, a positive significant correlation was found between duration of exposure and $\mathrm{FEV}_{1.0}$ reductions over a work shift $(\mathrm{r}=+0.40 ; \mathrm{P}<0.01)$ while there was a non-significant negative correlation $(r=-0.05 ; P>0.05)$ between age and $F E V_{1 \cdot 0}$ reductions when the effect of duration of exposure was eliminated. The partial correlation coefficient between acute FEV $_{\mathbf{1} \cdot 0}$ changes and duration of exposure was higher in subjects exposed to cotton dust for up to 11 years $(r=+0.516 ; P<0.01)$ than in those exposed for more than 11 years $(\mathrm{r}=+0.322 ; \mathrm{P}<0.05)$. Separate calculations for byssinotics exposed to cotton dust for 11 years or less gave a significant correlation between acute $\mathrm{FEV}_{1 \cdot 0}$ changes and duration of exposure $(\mathrm{r}=+0.541 ; \mathrm{P}<0.05)$ while for byssinotics with exposure for more than 11 years the partial correlation coefficient was not significant $(\mathrm{r}=+0.291 ; \mathrm{P}>0.05)$.

FEV $_{1 \cdot 0}$ expressed as a percentage of FVC before and after a work shift (Table III) has shown that the acute ventilatory change in byssinotics with a longer duration of exposure is mostly obstructive with a greater reduction in $\mathrm{FEV}_{1 \cdot 0}$ than FVC.

In Table IV mean FEV $_{1 \cdot 0}$ and PEF reductions during the shift are presented in four groups of cotton workers classified according to respiratory symiptoms. Byssinotics with other respiratory symptoms (persistent cough, persistent sputum,
T A B LE IV

MEAN FEV ${ }_{1.0}$ AND PEF CHANGES DURING THE SHIFT IN WORKER'S WITH OR WITHOUT BYSSINOSIS AND/OR OTHER RESPIRATORY SYMPTOMS

\begin{tabular}{|c|c|c|}
\hline \multirow[b]{2}{*}{ Group } & \multicolumn{2}{|c|}{ Changes } \\
\hline & $\underset{(\mathrm{ml})}{\mathrm{FEV}_{1 \cdot 0}}$ & $\underset{(1 / \mathrm{min})}{\text { PEF }}$ \\
\hline $\begin{array}{l}\text { With byssinosis and other respiratory } \\
\text { symptoms } \\
\text { With byssinosis, without other respiratory } \\
\text { symptoms } \\
\text { Without byssinosis, with other respiratory } \\
\text { symptoms } \\
\text { Without any respiratory symptoms }\end{array}$ & $\begin{array}{l}-250 \\
-245 \\
-151 \\
-147\end{array}$ & $\begin{array}{l}-46 \\
-42 \\
-30 \\
-25\end{array}$ \\
\hline
\end{tabular}

Other respiratory symptoms = persistent cough, persistent sputum, chronic bronchitıs, dyspnoea grade 3 and 4

chronic bronchitis, or dyspnoea grade 3 or 4 ) had the highest mean FEV $_{1 \cdot 0}$ and PEF reductions, followed by byssinotics without other respiratory symptoms. Much lower mean reductions of $\mathrm{FEV}_{1 \cdot 0}$ and PEF were found in non-byssinotics with other respiratory symptoms. Workers with no respiratory symptoms had the smallest mean reductions.

EFFECT OF BRONCHODILATOR Table $V$ shows the mean FEV 1.0 changes over a work shift and the effect of inhalation of the bronchodilator (Alupent) at the end of the first shift in the week. In all the workers in mill B as well as in the non-byssinotics in mill $\mathbf{A}$ the inhalation of Alupent restored the mean $\mathrm{FEV}_{1.0}$ to its pre-shift value (the difference between mean FEV $_{1.0}$ before the shift and after inhalation of the bronchodilator after the shift was not significant, $P>0.05$ ). In byssinotics in mill 
T A B L E V

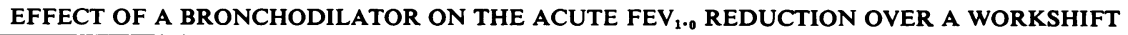

\begin{tabular}{|c|c|c|c|c|c|c|c|}
\hline & \multirow[b]{2}{*}{ Group } & \multirow[b]{2}{*}{ No. } & \multicolumn{5}{|c|}{ Mean FEV $_{1.0}(\mathrm{ml})$} \\
\hline & & & $\begin{array}{c}\text { Before } \\
\text { Work } \\
1\end{array}$ & $\begin{array}{l}\text { After } \\
\text { Work } \\
2\end{array}$ & $\begin{array}{c}\text { Difference } \\
\mathbf{1 - 2} \\
\mathbf{P}\end{array}$ & $\begin{array}{c}\text { After } \\
\text { Inhalation } \\
\mathbf{3}\end{array}$ & $\begin{array}{c}\text { Difference } \\
1-3 \\
\mathbf{P}\end{array}$ \\
\hline Mill A & $\begin{array}{l}\text { With byssinosis } \\
\text { Without byssinosis }\end{array}$ & $\begin{array}{l}12 \\
18\end{array}$ & $\begin{array}{l}2641 \\
2797\end{array}$ & $\begin{array}{l}2295 \\
2588\end{array}$ & $\begin{array}{l}<0.01 \\
<0.01\end{array}$ & $\begin{array}{l}2568 \\
2763\end{array}$ & $\begin{array}{l}<0.01 \\
\text { NS }\end{array}$ \\
\hline Mill B & $\begin{array}{l}\text { With byssinosis } \\
\text { Without byssinosis }\end{array}$ & $\begin{array}{l}14 \\
32\end{array}$ & $\begin{array}{l}3272 \\
3280\end{array}$ & $\begin{array}{l}3075 \\
3165\end{array}$ & $\begin{array}{l}<0.01 \\
<0.01\end{array}$ & $\begin{array}{l}3315 \\
3280\end{array}$ & $\begin{array}{l}\text { NS } \\
\text { NS }\end{array}$ \\
\hline
\end{tabular}

NS $=$ not significant $(P>0.05)$.

T A B L E V I

FUNCTIONAL GRADES OF COTTON DUST EFFECTS

\begin{tabular}{|c|c|c|c|c|c|c|}
\hline \multirow{2}{*}{ Grade } & \multirow{2}{*}{$\begin{array}{l}\text { FEV }_{1: 0} \text { Change } \\
\text { over Work Shift } \\
\text { (litres) }\end{array}$} & \multirow{2}{*}{$\begin{array}{c}\mathrm{FEV}_{1 \cdot 0} \% \text { of } \\
\text { Predicted }\end{array}$} & \multicolumn{2}{|c|}{ Mill A } & \multicolumn{2}{|c|}{ Mill B } \\
\hline & & & $\begin{array}{c}\text { With } \\
\text { Byssinosis } \\
(\%)\end{array}$ & $\begin{array}{c}\text { Without } \\
\text { Byssinosis } \\
(\%)\end{array}$ & $\begin{array}{c}\text { With } \\
\text { Byssinosis } \\
(\%)\end{array}$ & $\begin{array}{c}\text { Without } \\
\text { Byssinosis } \\
(\%)\end{array}$ \\
\hline $\begin{array}{l}\text { F } 0 \\
\text { F } 1 / 2 \\
\text { F } 1 \\
\text { F } 2 \\
\text { F } 3\end{array}$ & $\begin{array}{c}-0.05 \ldots 0 ; \text { or }+ \\
-0.06 \ldots-0.20 \\
\ldots \ldots-0.20 \\
\ldots \\
\ldots\end{array}$ & $\begin{array}{r}>80 \\
>80 \\
>80 \\
60-79 \\
<60\end{array}$ & $\begin{array}{r}16 \cdot 6 \\
16 \cdot 6 \\
41 \cdot 6 \\
16 \cdot 5 \\
8 \cdot 3\end{array}$ & $\begin{array}{r}12 \cdot 3 \\
42 \cdot 1 \\
28 \cdot 0 \\
16 \cdot 0 \\
1 \cdot 7\end{array}$ & $\begin{array}{c}23 \cdot 5 \\
47 \cdot 0 \\
29 \cdot 4 \\
0 \\
0\end{array}$ & $\begin{array}{c}32 \cdot 6 \\
39 \cdot 5 \\
27 \cdot 9 \\
0 \\
0\end{array}$ \\
\hline
\end{tabular}

A the $\mathrm{FEV}_{1 \cdot 0}$ remained significantly reduced despite the inhalation of Alupent.

CHRONIC EFFECTS OF EXPOSURE TO COTTON DUST In order to assess the degree of chronic ventilatory insufficiency the $\mathrm{FEV}_{1.0}$ was measured in all the workers after two days' absence from dust exposure and calculated as the percentage of the normal values obtained from the Veterans Administration nomogram for normal females of the same age and standing height. Workers in mill $A$ with and without byssinosis had significantly lower FEV $1 \cdot 0$ values, expressed as the percentage of the normal values (byssinotics $90.4 \%$; non-byssinotics $93.5 \%$ ), than those in mill B (byssinotics $102.4 \%$; nonbyssinotics $106.2 \%)(\mathrm{P}<0.05$ and $<0.01$ respectively).

Functional grades of cotton dust effects (Bouhuys et al., 1970) in workers in the two cotton mills are presented in Table VI as a supplement to the clinical grading system of byssinosis. The functional grading system includes an assessment of both the acute and chronic effects of vegetable dust on ventilatory capacity. A considerably smaller number of grades $F 0$ and $1 / 2$ were found in mill $\mathbf{A}$ as compared with mill $\mathbf{B}$, while the relative frequencies of grades $F 1, F 2$, and $F 3$ were much higher in mill $A$. In fact, no worker was found with functional grades F 2 or F 3 in mill B.

\section{DISCUSSION}

The two non-smoking female populations exposed for differing lengths of time to practically identical concentrations of the same type of airborne cotton dust differed markedly in the prevalence of chronic respiratory symptoms, acute ventilatory disturbance, reaction to inhalation of a bronchodilator, and in the degree of chronic ventilatory impairment.

The prevalence of chronic respiratory symptoms (persistent cough, persistent phlegm, chronic bronchitis, and dyspnoea) was found to be higher in byssinotics exposed to cotton dust for a longer period of time (Table II). As this group of workers was at the same time older, one could argue that these findings might be due to more advanced age. However, this is unlikely, since the prevalence of respiratory symptoms was practically the same in the non-byssinotics in the two mills studied, in spite of the great difference in mean age between the two groups of workers. Furthermore, byssinotics of the group with the longer exposure to cotton dust were found to have a significantly higher prevalence of non-specific respiratory symptoms than the non-byssinotics, while these differences were not significant in the group with a shorter duration of cotton dust exposure. Byssinotics would therefore appear more likely to develop non-specific respiratory symptoms than nonbyssinotics and, irrespective of age, the proba- 
bility of developing these symptoms increases with the length of exposure to cotton dust.

Although exposure to cotton dust during the shift caused significant acute reductions of the mean $\mathrm{FEV}_{1 \cdot 0}$, FVC, and PEF in all groups of cotton workers (Table III), the acute decrease in ventilatory capacity was greater in byssinotics with a longer rather than a short exposure to cotton dust irrespective of age. In contrast, the reduction in ventilatory function in workers without byssinosis was practically the same in both groups.

Chronic changes of ventilatory capacity develop only after prolonged exposure to cotton dust and they are greater in subjects with byssinosis.

The history of non-specific respiratory symptoms appears to predispose to an acute reduction of ventilatory capacity during shift work in all groups of workers.

Only advanced cases of byssinosis fail to respond completely to bronchodilator therapy at the end of a working shift.

Interestingly, the incidence of byssinosis was lower in workers with a longer duration of exposure to cotton dust $(17 \cdot 4 \%)$ than in those with a shorter exposure $(28.5 \%)$. This is undoubtedly due to selfselection, a great proportion of 'reactors' among older workers having left the factory in the early phase of their employment.

This investigation was supported in part by a grant (PL 480 Project 02-006-3) from the Bureau of Occupational Safety and Health, U.S. Public Health Service, Department of Health, Education and Welfare.

\section{REFERENCES}

Batawi, M. A. El., Schilling, R. S. F., Valic, F., and Walford, J. (1964). Byssinosis in the Egyptian cotton industry: changes in ventilatory capacity during the day. Brit. J. industr. Med., 21, 13.

Bouhuys, A., Gilson, J. C., and Schilling, R. S. (1970). Byssinosis in the textile industry. Arch. environm. Hlth, 21, 475 .

Wolfson, R. L., Horner, D. W., Brain, J. D., and Žuškin, E. (1969). Byssinosis in cotton textile workers. Respiratory survey of a mill with rapid labour turnover. Ann. intern. Med., 71, 257.

McKerrow, C. B., McDermott, M., Gilson, J. C., and Schilling, R. S. F. (1958). Respiratory function during the day in cotton workers: a study in byssinosis. Brit. J. industr. Med., 15, 75.

Molyneux, M. K. B., and Tombleson, J. B. L. (1970). An epidemiological study of respiratory symptoms in Lancashire mills, 1963-66. Brit.J. industr. Med., 27, 225.

Schilling, R. S. F., Bouhuys, A., and Gilson, J. C. (1971). A report on a conference on byssinosis. In: Proc. XVI int. Congr. occup. Hlth, Tokyo, Japan, 1969, p. 173.

-_, Vigliani, E. C., Lammers, B., Valic, F., and Gilson, J. C. (1964). A report on a conference on byssinosis. In: Proc. XIV int. Congr. occup. Hlth, Madrid, 1963, vol. 2, p. 137. Int. Congr. Ser. No. 62. Excerpta Medica, Amsterdam.

Wright, B. M. (1954). A size-selecting sampler for airborne dust. Brit. J. industr. Med., 11, 284.

- and McKerrow, C. B. (1959). Maximum forced expiratory flow rate as a measure of ventilatory capacity, with a description of a new portable instrument for measuring it. Brit. med.J., 2, 1041. 